\title{
Hydrologic response of a semi-arid watershed to spatial and temporal characteristics of convective rain cells
}

\author{
H. Yakir and E. Morin \\ Geography Department, The Hebrew University of Jerusalem, Mt. Scopus, Jerusalem 91905, Israel \\ Received: 14 September 2010 - Published in Hydrol. Earth Syst. Sci. Discuss.: 5 October 2010 \\ Revised: 18 January 2011 - Accepted: 19 January 2011 - Published: 31 January 2011
}

\begin{abstract}
Rain can be measured and represented in many ways such as point data from rain gauges, grid data from meteorological radar, or interpolated data. In this paper we represent rain fields by implementing a rain cell model of convective rain cells. The rain fields are used as an input to a hydrological model to test the watershed response to spatial and temporal characteristics of the rain cells. As a case study we tested an extreme storm event over a semi-arid watershed in southern Israel. The rain cell model was found to simulate the rain storm adequately. The use of these modeled cells allowed us to test the sensitivity of the watershed hydrological response to rain cell characteristics and it was found that the watershed is mainly sensitive to the starting location of the rain cell. Relatively small changes in the rain cell's location, speed and direction may increase watershed peak discharge by three-fold.
\end{abstract}

\section{Introduction}

Rainstorms in semi-arid environments are often characterized by a large variability in time and space, are limited in size and cover only part of the watershed (Marco and Valdes, 1998; Syed et al., 2003). A number of studies have shown that the hydrologic response of watersheds in semi-arid climate regimes is sensitive to convective rain cells attributes in time and space (Saulnier and Le Lay, 2009) and also the spatial variability of the rain data (Bonnifait et al., 2009). Most of these studies take one of the following approaches: (1) analysis of real rainstorms and inspecting the hydrologic response to the storm characteristics (Arnaud et al., 2002; Younger et al., 2009) or, (2) generating synthetic rainstorm data with a range of characteristics and applying a hydrolog-

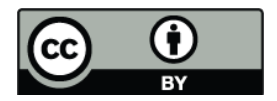

Correspondence to: E. Morin

(msmorin@mscc.huji.ac.il) ical model to test the probable hydrological response (Gabellani et al., 2007; Shah et al., 1996; van Werkhoven et al., 2008). The main deficiency of the first approach is the restriction to the very specific conditions of the examined rainstorm.The second approach is often applied as a part of rainstorm stochastic models that are aimed on providing a description of the spatial and temporal distribution of rainfall fitted to the climatological characteristics of a specific region (Gupta and Wymire, 1979; Northrop, 1998; Wheater et al., 2005; Mehrotra et al., 2006; Leonard et al., 2008; Cowpertwait, 2010; among others). Many of the stochastic models are based on the theory of point processes with rain cells as their building units represented by space-time models as explained below. The present study uses a different approach, first suggested by Morin et al. (2006), where the two methods mentioned above are combined. The analysis is based on real rainstorm data for which a rain cell model is fitted and then the rain cells characteristics are changed. Combined with a hydrological model, the effect of the changes in the rain on the runoff hydrograph is tested.

Rain cell models are designed to represent the basic elements of the convective rain storm, the rain cells, and describe their spatial and temporal evolution. These models are commonly applied to rainfall data from meteorological radar systems which provide detailed space-time rain rate information (Barnolas et al., 2010; Morin et al., 2006). Several studies focused on rain cell modelling describing circular or elliptical cell shapes (Feral et al., 2003; Karklinsky and Morin, 2006; Northrop, 1998; von Hardenberg et al., 2003; Willems, 2001; Cox and Isham, 1988), with the rain rate spatial distribution within the cell represented in one of the following ways:

1. Rain cells with a constant rain rate throughout the cell (Northrop, 1998; Cox and Isham, 1988).

2. Cells with a Gaussian decay of rain from the cell center (Willems, 2001; Morin et al., 2006; Northrop, 1998),

Published by Copernicus Publications on behalf of the European Geosciences Union. 
This model fits mainly to the core of the convective rain cell characterized by a relatively fast decay of rain rates from the center outwards but not to the outer part of the cell with typically lower gradients (Feral et al., 2003).

3. Cells with an exponential decay of rain from the cell center (Capsoni et al., 1987a, 1987b; Willems, 2001; von Hardenberg et al., 2003). For example, the EXCELL model Capsoni et al. (1987a) describes the rain cells as an ellipsoid whereby the rain decays from the center exponentially. This model creates cells with overestimation of the rain rate in the center (Feral et al., 2003).

4. Combination of the Gaussian and exponential decay functions. The HYCELL model (Feral et al., 2003) combines the two equations to describe both the high rain rates with the fast decay at the cell core and the lower rain rates and gradients at the margins. The HYCELL rain cell model is used in the current study.

It should be noted that rain fields are often represented as a superposition of several rain cells and thus their spatial structure is more complex than the fields of the individual cells. Some of the models account also for the rain cell dynamic where the cells are often assumed to move in a constant velocity and direction and to maintain constant characteristics during their life time (e.g., Northop, 1998). Direction and velocity of rain cells can be derived by applying tracking algorithms to observed rain cells. The TITAN model (Dixon and Wiener, 1993; Johnson et al., 1998) used an optimization process to obtain the most likely option for the cell movements, while other models (Han et al., 2008; Rinehart and Garvey, 1978) track the cells by recognizing which of the cells in the next time step has the highest correlation to the current cell.

The hydrologic response of watersheds in semi-arid climates is known to be influenced by the rainstorm properties such as rainstorm direction, location, and velocity. Rainstorms moving upstream typically generate hydrographs at the catchment outlet with an early and slow rise, medium peak discharge and a slow decay, while storms moving downstream typically cause a later flow at the catchment outlet with a higher peak and a relatively fast rise and decay of the hydrograph (Singh, 1997). A different study, however, found it was upstream moving storms that produced higher peaks than downstream moving storms (van Werkhoven et al., 2008). Morin et al. (2006) showed that directions which caused the cell to remain longest over the watershed produced the highest flow peaks. Chang (2007) found that the direction affects the flow timing more than the rain intensities. The location of the storm over the main channel is also of great importance (Morin et al., 2006) because of the averaging effect of flow routing through a channel network caused by unifying travel times from different locations (Zoccatelli et al., 2010). The interaction between the shape of the watershed and the location of the storm affects runoff generation; a storm closer to the outlet produces more runoff (Syed et al., 2003; van Werkhoven et al., 2008). Storm velocity determines the amount of rainfall over the watershed and the amount of generated runoff. Slower storms produce higher magnitude runoff flows (Singh, 1997; Doswell et al., 1996).

The main objective here is to study the hydrologic response of a semi-arid watershed to rain cell characteristics. This is achieved using the following three stages:

1. Applying a model to describe the rain cells and their characteristics in time and space

2. Using the model generated rain cells as an input to a calibrated hydrological model

3. Inspecting the relations between the rain cell characteristics and the watershed hydrological response, and testing the watershed sensitivity to changes in the rain cells characteristics.

\section{Study area and data}

\subsection{The Negev desert climate}

The Negev desert covers an area of about $10000 \mathrm{~km}^{2}$ in southern Israel (Fig. 1a). It is bounded by the Mediterranean Sea from north-west, the Dead-sea from north-east and the Gulf of Aqaba from the south. The central Negev Mountains reach a height of about $1000 \mathrm{~m}$ a.s.l. The Beqa watershed drains the Negev western slopes toward the Mediterranean Sea (Kahana et al., 2002).

The Negev desert climate is classified as arid to semiarid according to the Koeppen climate classification (Ahrens, 2003). Rain in the Negev could be local or widespread; distinguishing between the two different rain structures is important since the rain rate and duration is different between the two cases (Dayan and Sharon, 1980). Most of the major runoff events in the Negev are caused by convective storms composed of several rain cells. Since each rain cell has a short lifespan, the cells are often organized into a larger structure in which cells are generated and disappear, allowing the storm to last longer than a normal rain cell (Doswell et al., 1996). Therefore the storm movement direction is specified by both wind and topography and the cell generation processes inside the storm.

Convective rain cells can be clearly recognized from meteorological radar data as areas with high rain rates. In semiarid and arid areas of Israel it was found that these cells are round or elliptic, with areas less than $100 \mathrm{~km}^{2}$ and, in some cases, the cells were bound within a low-rate rain area (Dayan and Morin, 2006; Karklinsky and Morin, 2006). 


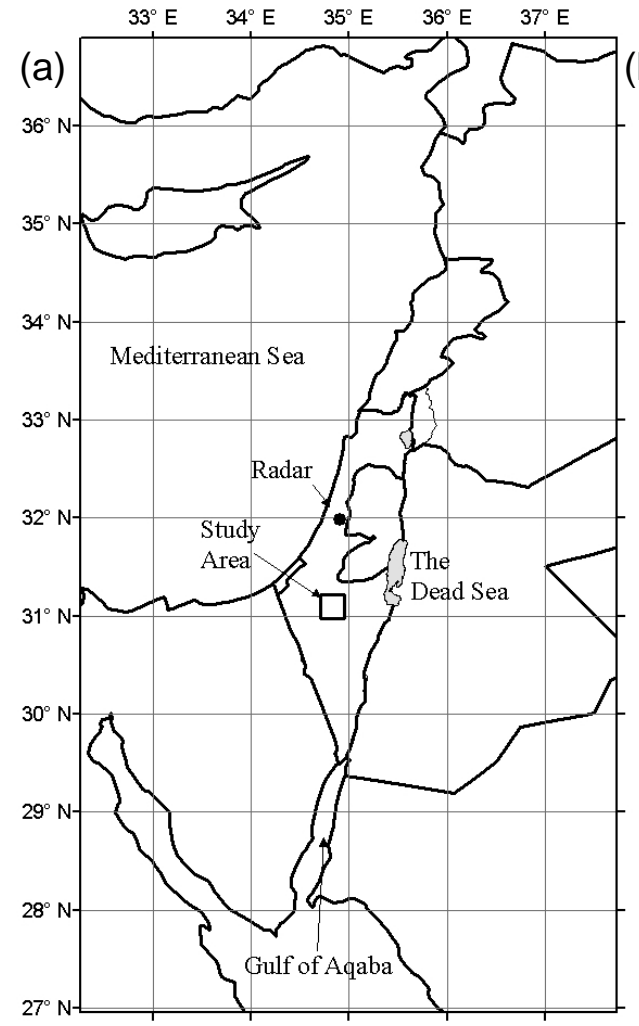

(b)

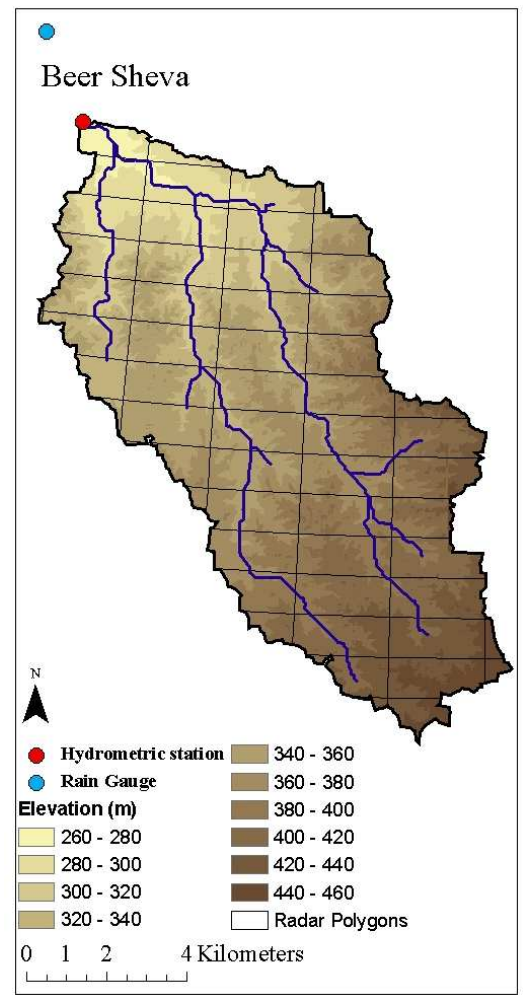

Fig. 1. (a) Regional map, (b) The Beqa watershed map. Red circle indicates the hydrometric station at the watershed outlet, the blue circle marks the closest rain gauge, and the radar polygons are marked in black.

\subsection{Watershed characteristics}

The $94 \mathrm{~km}^{2}$ Beqa watershed (Fig. 1b) is located in south-west Israel with its outlet south of the city of Beer-Sheva. The watershed height spans from 460 to $260 \mathrm{~m}$ and most of the area is rural, partly covered by cultivated fields and sparsely inhabited territories.

From long-term daily rain data (1957-2002) obtained from the closest rain gauge (located in Beer-Sheva), the mean annual rainfall in the region is $196 \mathrm{~mm}$ with a standard deviation of $83 \mathrm{~mm}$. On average there are 40 rainy days that occur between November and March, while summer is hot and dry.

Between the years 1947 and 2006, 290 flows were measured in the Beqa watershed. The maximal observed peak was $240 \mathrm{~m}^{3} / \mathrm{s}$ in December 1951 and the mean annual runoff is $0.32 \times 10^{6} \mathrm{~m}^{3}$.

\subsection{The rain storm}

The rain storm selected for the study is an extreme storm event that occurred on 20-23 December 1993, and which caused major floods in the Negev area (Ziv et al., 2005). Over the Beqa watershed the storm occurred on the 22-23 of December. Rain was mostly in the form of afternoon convective showers, with rain totals that in some cases exceeded the long-term December averages. This rainstorm resulted in extreme flash floods with return periods of 35-100 years for several watersheds.

The rain gauge near the Beqa watershed measured $24 \mathrm{~mm}$ for this storm but the meteorological radar data indicate more than $70 \mathrm{~mm}$ over some parts of the watershed (Fig. 2). The resulted flash-flood (Fig. 3) had a peak discharge of $81.4 \mathrm{~m}^{3} / \mathrm{s}$, which is fifth in the watershed record (1951-2006) and with a return period of about 10 years. The flash-flood event was the largest one with sufficient hydrological and meteorological data and therefore selected for this study.

\section{Methods}

Data from the Shacham meteorological radar system located at Ben-Gurion airport (Fig. 3a), $90 \mathrm{~km}$ distance from the studied watershed, were used in this research. The radar data resolution is $5 \mathrm{~min}$ in time and $1.4^{\circ} \times 1 \mathrm{~km}$ in space. Radar maps at polar coordinates are transformed into $1 \times 1 \mathrm{~km}^{2}$ Cartesian maps of $34 \times 34 \mathrm{~km}^{2}$ around the watershed area (Fig. 1b).

Radar reflectivity data, $\mathrm{Z}\left(\mathrm{mm}^{6} \mathrm{~m}^{-3}\right)$, are translated into rain rate data, $R(\mathrm{~mm} / \mathrm{h})$, using the methodology described in Morin and Gabella (2007). In this method an initial power 


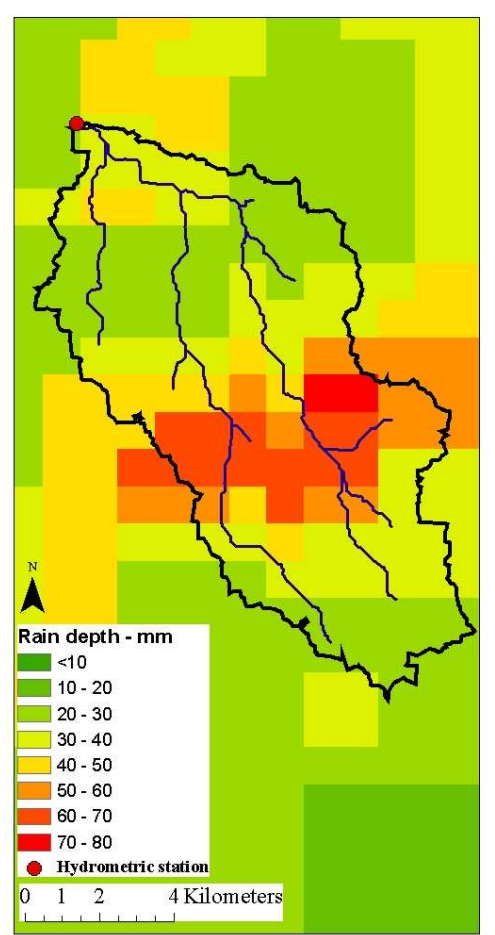

Fig. 2. Accumulated rain depth over the Beqa watershed from the storm of 20-23 December 1993. Data are based on calibrated radar data.

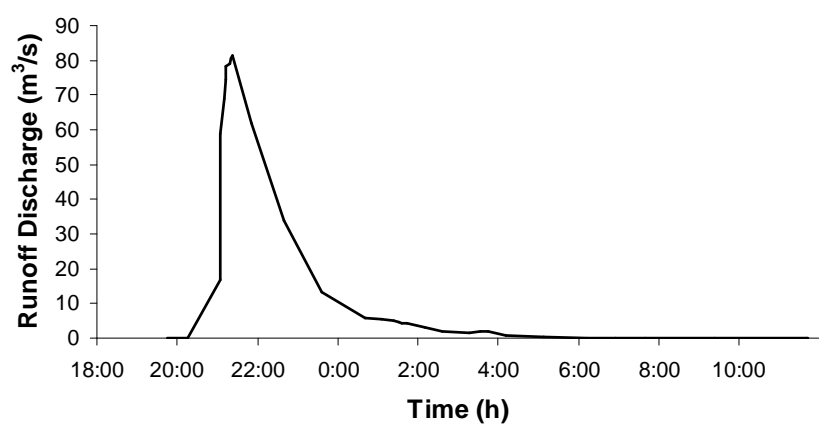

Fig. 3. The observed hydrograph for the rainstorm of 20-23 December 1993.

law relationship is applied with an exponent value of 1.5 and then a correction factor is applied to the initial rain rate estimates depending on the distance from the radar, topographic height and latitude (Morin and Gabella, 2007).

\subsection{Rain cell identification}

The first step of the rain cell modelling process is segmentation. A segment including a rain cell is defined as the area around a local maximum, contoured by a threshold rain rate, $R_{2}(\mathrm{~mm} / \mathrm{h})$ or a neighbour segment. In the segmentation process the rain rate matrix is scanned from the highest value down; each time a local maximum is found it is defined as a new rain cell segment. The segment is then expanded by adding neighbour pixels. Segments that are smaller than $9 \mathrm{~km}^{2}$, or have a maximum rain rate of less than $30 \mathrm{~mm} / \mathrm{h}$, are removed. Adjacent segments where the difference between the peak and the pixel bordering the segments is less than 25 $\mathrm{mm} / \mathrm{h}$ are united into a single segment.

Each segment is fitted with an ellipsoid cell shape as described in Feral et al. (2000) and the cell features are extracted: segment area $\left(\mathrm{km}^{2}\right)$, maximal rain rate $(\mathrm{mm} / \mathrm{h})$, sum of rain rates $\left(\mathrm{km}^{2} \times \mathrm{mm} / \mathrm{h}\right)$, Rrms - Root mean square of the rain rates in the segment $(\mathrm{mm} / \mathrm{h})$, ellipsoid center location, ellipsoid major radius length $(\mathrm{km})$, ellipsoid minor radius length $(\mathrm{km})$, ellipticity (ratio of minor to major radius lengths) and the orientation (deg.) of the ellipsoid major radius.

The HYCELL rain cell model is fitted to the segment based on the derived features as described in Feral et al. (2003):

$R(x, y)=\left\{\begin{array}{l}R_{\mathrm{G}} \exp \left[-\left(\frac{x^{2}}{a_{\mathrm{G}}^{2}}+\frac{y^{2}}{b_{\mathrm{G}}^{2}}\right)\right] \text { if } R \geq R_{1} \\ R_{\mathrm{E}} \exp \left[-\left(\frac{x^{2}}{a_{\mathrm{E}}^{2}}+\frac{y^{2}}{b_{\mathrm{E}}^{2}}\right)^{1 / 2}\right] \text { if } R_{2} \leq R \leq R_{1}\end{array}\right\}$

As mentioned above, a rain cell is defined above a threshold value $\left(R_{2}\right)$, where $R_{1}(\mathrm{~mm} / \mathrm{h})$ is a threshold rain rate that separates the exponential function (cell outer part) and the Gaussian function (cell inner part) as described in Eq. (1): $x, y$ are the point coordinates relative to the cell center, $R_{\mathrm{E}}$ and $R_{\mathrm{G}}(\mathrm{mm} / \mathrm{h})$ are peak rain rate for the exponential and Gaussian functions, respectively, and, $a_{\mathrm{E}}, a_{\mathrm{G}}, b_{\mathrm{E}}, b_{\mathrm{G}}(\mathrm{km})$ represent the decay rate along the major $(a)$ and minor $(b)$ of the exponential $(E)$ and Gaussian $(G)$ radii.

The three parameters $R_{1}, R_{\mathrm{E}}$ and $R_{\mathrm{G}}$ are fitted for each rain cell by minimizing the target function:

$\zeta=\left|\frac{\bar{R}_{\mathrm{H}}}{\bar{R}_{\mathrm{r}}}-1\right|+\left|\frac{\left(R_{\mathrm{rms}}\right)_{\mathrm{H}}}{\left(R_{\mathrm{rms}}\right)_{\mathrm{r}}}-1\right|+\left|\frac{R_{\mathrm{H}}}{R_{\mathrm{r}}}-1\right|$

where $\bar{R}_{\mathrm{H}}$ and $\bar{R}_{\mathrm{r}}(\mathrm{mm} / \mathrm{h})$ are the rain rate average according to the model and the radar, respectively, $\left(R_{\mathrm{rms}}\right)_{\mathrm{H}}$ and $\left(R_{\mathrm{rms}}\right)_{\mathrm{r}}$ $(\mathrm{mm} / \mathrm{h})$ are the root mean square rain rates according to the model and the radar, respectively, and, $R_{\mathrm{H}}$ and $R_{\mathrm{r}}(\mathrm{mm} / \mathrm{h})$ are the rain rate maximum according to the model and the radar, respectively.

The parameters $a_{\mathrm{E}}, a_{\mathrm{G}}, b_{\mathrm{E}}$ and $b_{\mathrm{G}}$ are calculated using Eqs. (3-6)

$$
\begin{aligned}
& b_{\mathrm{E}}=\sqrt{\frac{A_{\mathrm{r}}}{\pi e_{\mathrm{r}} \ln ^{2}\left(\frac{R_{\mathrm{E}}}{R_{2}}\right)}} \\
& a_{\mathrm{E}}=e_{\mathrm{r}} b_{\mathrm{E}} \\
& b_{\mathrm{G}}=\frac{a_{\mathrm{G}}}{e_{\mathrm{r}}}
\end{aligned}
$$


$a_{\mathrm{G}}=\sqrt{\frac{a_{\mathrm{E}} \ln ^{2}\left(\frac{R_{\mathrm{E}}}{R_{1}}\right)}{\ln \left(\frac{R_{\mathrm{G}}}{R_{1}}\right)}}$

It is assumed that the rain cells' parameters remain constant in time and that the cells move at a constant velocity and direction during their life time. In order to derive these parameters from the data, the identified rain cells were tracked in time. In the current study a manual tracking procedure was applied where every cell in each time step was examined and a decision was made whether this cell was new or a cell from the former time step that moved. The cell parameters were then taken as the median value throughout the cell's life span. While the simplified assumptions above allow the present model being parsimonious they imply that changes of rain cell properties during its passage are not accounted for.

\subsection{Hydrological model calibration and application}

The hydrological model used in this research is an eventbased distributed hydrological model describing the generation of rainfall excess, routing of surface water over hillslopes and in channels toward the outlet, with infiltration into the channel alluvium. The model was used in previous studies to simulate watershed runoff for arid and semi-arid watersheds (Morin et al., 2009; Bahat et al., 2009) and was calibrated for the studied storm event.

The watershed was divided into 17 sub-catchments. Rain rate is assumed to be uniform over each sub-catchment and is computed as the spatial average of the rain rate over the subcatchment. When the accumulated rainfall depth is larger than the initial loss parameter value $(20 \mathrm{~mm})$ and the rain rate is higher than the constant infiltration capacity $(10 \mathrm{~mm} / \mathrm{h})$, rainfall excess is generated as the difference between the rain rate and the infiltration capacity. The Kinematic wave equation is used to compute water routing over the hillslopes and in the channels (Bahat et al., 2009). Manning parameters was taken as 0.08 for hillslopes and 0.025 for channels, and the constant alluvium infiltration rate was $100 \mathrm{~mm} / \mathrm{h}$.

\subsection{Sensitivity analysis}

The sensitivity of the watershed hydrological response to three convective rain cell parameters was examined. The parameters are: rain cell starting point, rain cell movement direction, and rain cell speed. The sensitivity was tested in two approaches. The first was a local sensitivity analysis of one parameter while keeping the other parameters fixed. The second was a global sensitivity analysis, a variance based method (Saltelli et al., 2006) in which values of all three parameters are changed simultaneously and the contribution of each parameter and of the interactions between them to the overall variance is examined.

\section{Results}

\subsection{Rain cell modelling}

The rainstorm is composed of 329 radar maps from which 141 segments were found and the HYCELL rain cell parameters have been derived. A good fit $\left(R^{2}\right.$ larger than 0.85$)$ is obtained between modelled rain cells and the rain segment data comparing maximum rain rate, areal average rain rate, rain area and total rain (the sum of rain in all of the cell's pixels) for all 141 cells (Fig. 4), suggesting the model as very capable of describing the rain cells elements.

Rain cell tracking was applied and 56 cells were found in all the time steps. For each rain cell the median of the HYCELL parameters were derived (see Sect. 3.1 above) and the dynamic parameters were computed: starting location, movement direction, movement speed and cell life duration. Figure 5 presents the distribution of cell maximum rain rate, area, and ellipticity. The average of the rain cell maximum rain rate is $77 \mathrm{~mm} / \mathrm{h}$, with more than half of the cells maximums between 30 and $80 \mathrm{~mm} / \mathrm{h}$. The average cell area average is $100 \mathrm{~km}^{2}$. Since the watershed area is $94 \mathrm{~km}^{2}$, it implies that about half of the cells are larger than the watershed. The average ellipticity of the cells is 0.58 , with a value of one representing a circle, thus most of the cells can be described as ellipsoids. Figure 6 presents a histogram of cell life span. For the 56 cells the average life span was $12.6 \mathrm{~min}$ (2.5 time steps) while the maximum life span for a single cell was $70 \mathrm{~min}$.

\subsection{Hydrological model results}

Two rainfall inputs were fed into the hydrological model: the original radar rain rate data and the rain rates as obtained from applying the rain cell model. The computed outlet runoff hydrographs are similar for the two inputs (Fig. 7) suggesting that the rain cell model represents the important elements of the storm. There is, however, a time shift between the observed and the modelled hydrographs, which is suspected to be a result of inaccuracies in the observed flow timing caused by the mechanical recorders of the hydrometric stations.

By running the model with one rain cell at a time it was found that only one major cell (referred here as the "flooding cell") produced flow at the watershed outlet while the rest of the cells did not generate outlet flow individually. No outlet flow was generated even if all cells except to the flooding cell were input to the model. The outlet hydrograph generated from the flooding cell, as computed by the model, is presented in Fig. 8.

\subsection{Sensitivity analysis}

Sensitivity analysis was conducted by varying characteristics of the flooding rain cell and examining the effect on total rain and outlet runoff (peak discharge and runoff volume). The 

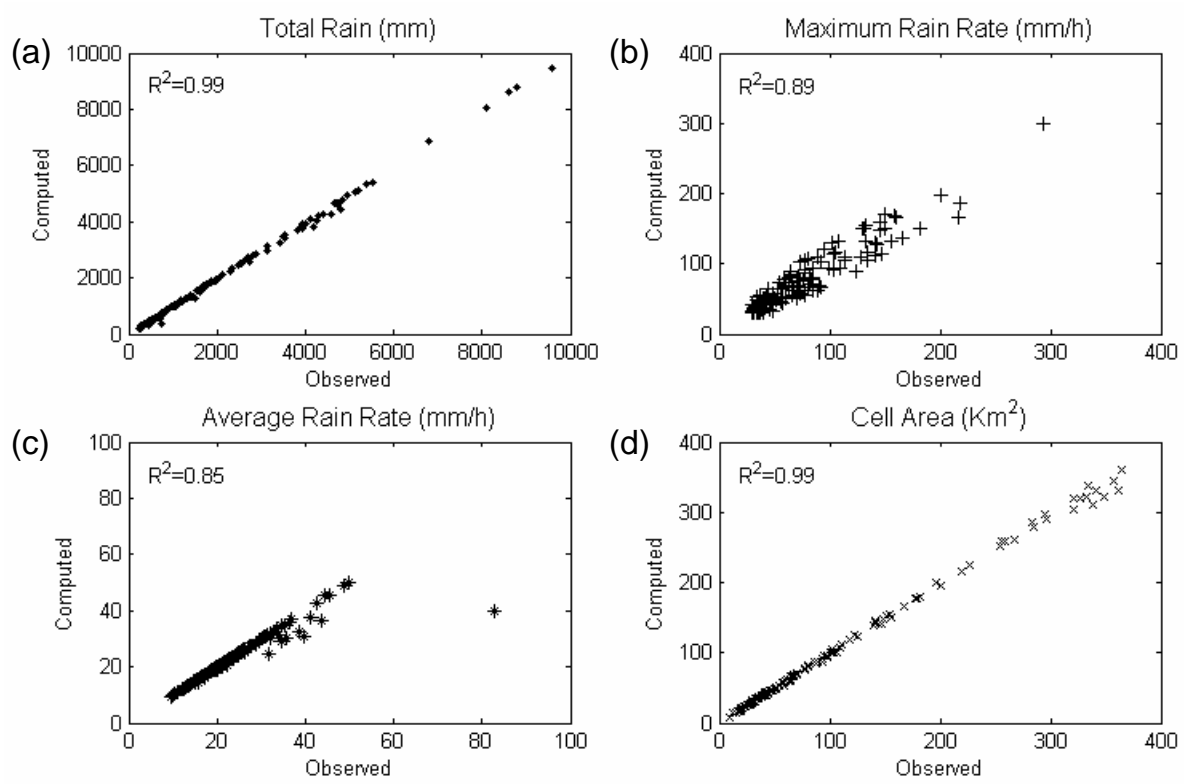

Fig. 4. Correlations between the rain segment data and the model generated rain cells.
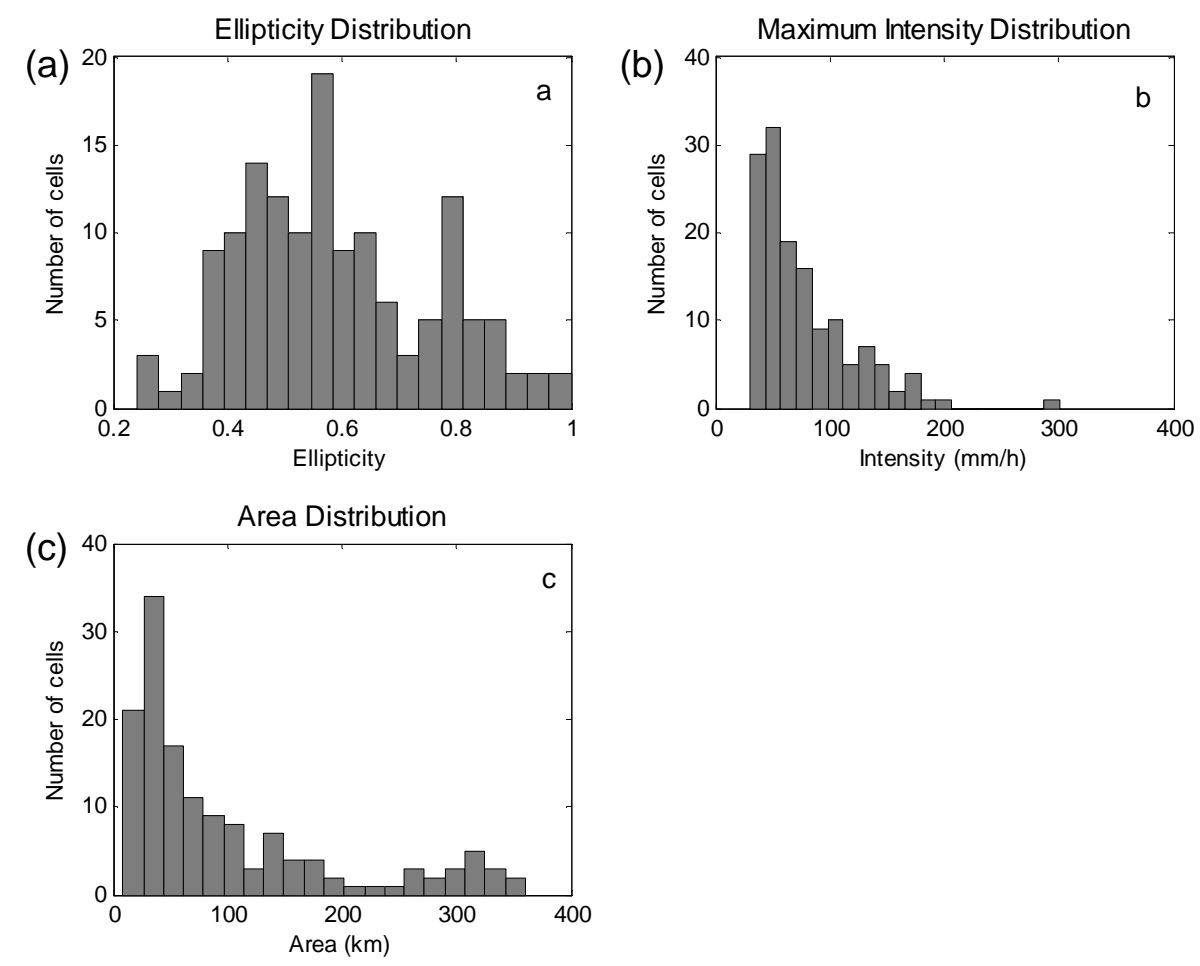

Fig. 5. Histograms of: (a) maximum rain rate $(\mathrm{mm} / \mathrm{h})$, (b) segment area $\left(\mathrm{km}^{2}\right)$, and (c) ellipticity for the 141 rain cells derived for the analyzed storm.

flooding cell starting location was changed to be each one of the $34 \times 34$ pixels, leaving all the other cell parameters unchanged. The total rain over the watershed $(\mathrm{mm})$, peak discharge $\left(\mathrm{m}^{3} / \mathrm{s}\right)$ and total runoff volume $\left(\mathrm{m}^{3}\right)$ computed for each starting location are shown in Fig 9. These results show that if the rain cell starting location was about $4 \mathrm{~km}$ northwest of the original point, the peak discharge and runoff volume could be doubled. From examining the relation between 


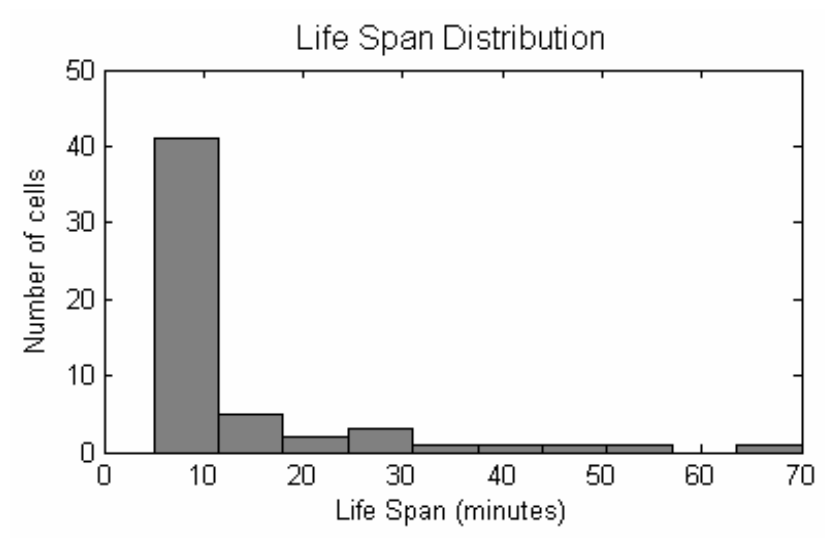

Fig. 6. Life span histogram for the 56 rain cells.

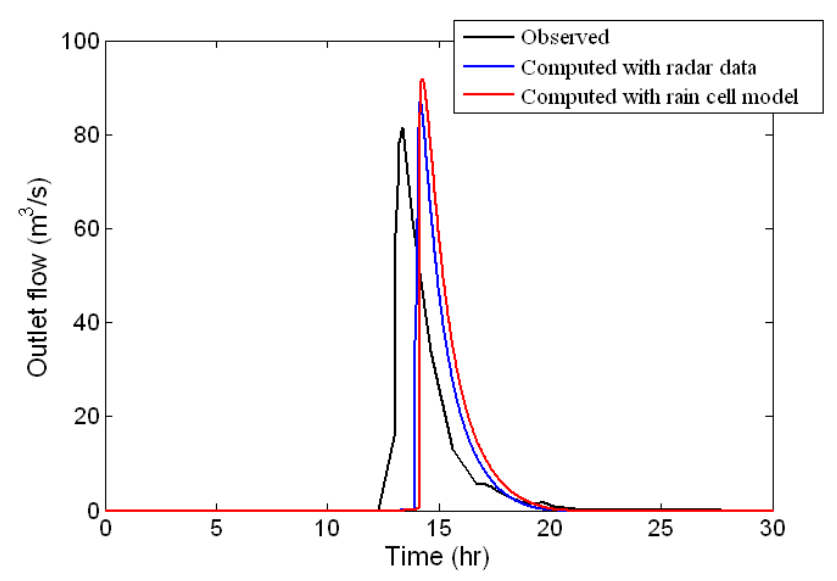

Fig. 7. The observed hydrograph (black), the modeled hydrograph computed using the radar data (blue) and the modeled hydrograph computed using the rain cell model data (red).

the distance of the cell center from the outlet and the peak discharge (Fig. 10), cells that originated too close or too far from the outlet had relatively low peak discharge while at distances of 8-12 km from the outlet the peak discharges were highest. These differences are caused by the larger amount of rainfall precipitated over the watershed when the cell starts from mid-value distances as compared to the two extremes.

The effect of cell movement direction on the watershed hydrological response is shown in Fig. 11. Three different starting locations are considered: the original starting point, the watershed outlet and the upstream edge of the watershed. The direction that produced the highest peak discharge was the direction in which the cell spent the majority of its lifespan over the watershed. For a cell starting at the original starting point, $\mathrm{a} 65^{\circ}$ rotation counter-clockwise would double the peak discharge. For a cell starting at the watershed outlet a $110^{\circ}$ rotation clockwise from the original cell direction would produce the highest peak discharge while movement in the original direction would not produce any runoff. As for

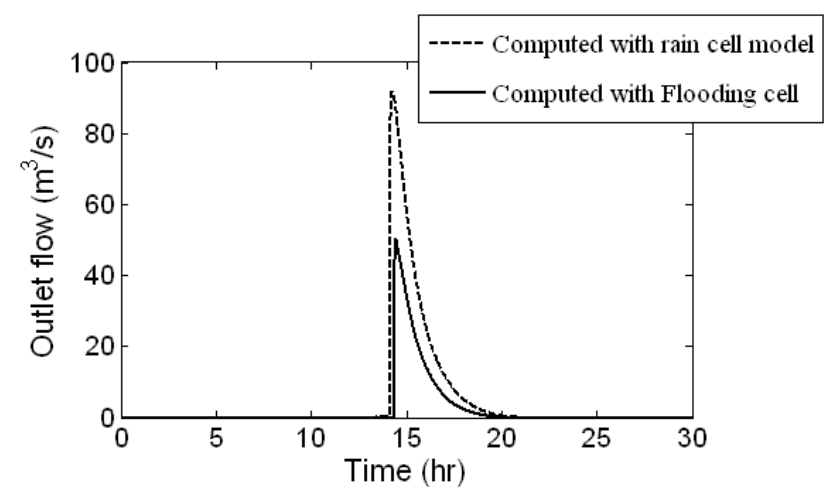

Fig. 8. Hydrograph using the modeled hydrograph computed using all the rain cell model data (dotted line) and the modeled hydrograph using only the flooding cell data (solid line).

a cell starting upstream, a rotation of $95^{\circ}$ counter-clockwise from the original direction would produce the highest peak discharge.

The rain cell speed was changed between 0 to $16 \mathrm{~m} / \mathrm{s}$ while keeping the rest of the characteristics unchanged. A decrease in peak discharge as the speed increases can be seen (Fig. 12) due to the fact that higher velocities cause the cell to pass over the watershed faster and with less rain.

A global sensitivity analysis of runoff peak discharge to rain cell location, direction and speed was conducted and the sensitivity indexes are presented in Table 1 . The most influencing factor is the cell location, both as a main effect (caused by this factor only) and total effect (caused by the factor and all its interactions with other factors). Rain cell speed is the second most important of the three factors examined here.

\section{Summary and discussion}

The rainstorm of the 22-23 December 1993 over the Beqa watershed was analyzed. Rain maps obtained from radar data were divided into segments and for each segment rain cell model (HYCELL) was applied. The rain cells were tracked in time yielding 56 rain cells. The modelled cells were used as an input to the hydrological model and one of the cells was found to be the most significant in generating the flash flood. Sensitivity analysis was conducted based on this major cell and it was found that the watershed runoff was very sensitive to the convective rain cell characteristics. In particular, a small change of cell location, direction and speed, could cause a three-fold higher flood peak discharge.

Sensitivity of the watershed hydrological response to rain cell characteristics was investigated in the current study using a unique approach combining real storm data and a rain cell model. Although more cases need to be studied, several advantages and potential applications of the presented approach can be suggested: 

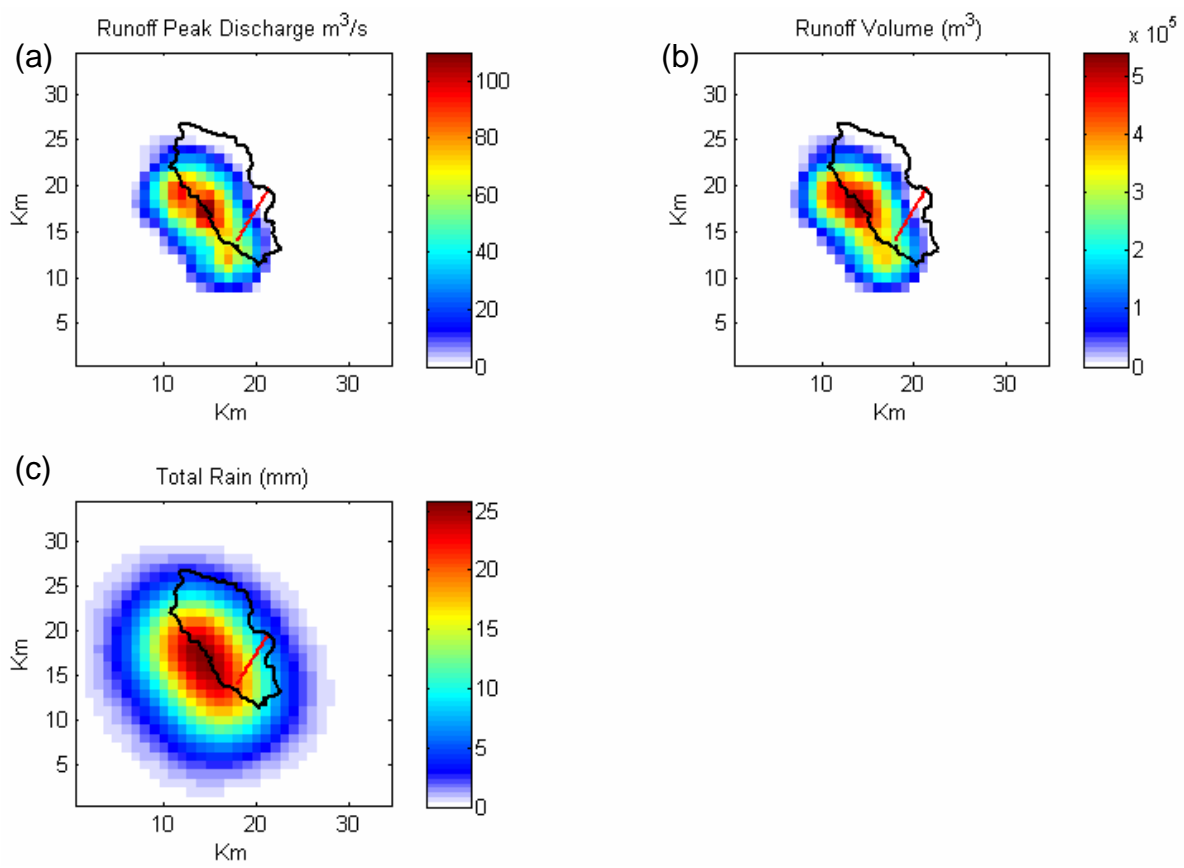

Fig. 9. (a) The peak discharge $\left(\mathrm{m}^{3} / \mathrm{s}\right)$ (b) the total runoff volume $\left(\mathrm{m}^{3}\right)$ and (c) total rain over the watershed (mm), for each starting point of the flooding cell. The original direction of the flooding cell over the basin (black) is indicated by the red line.

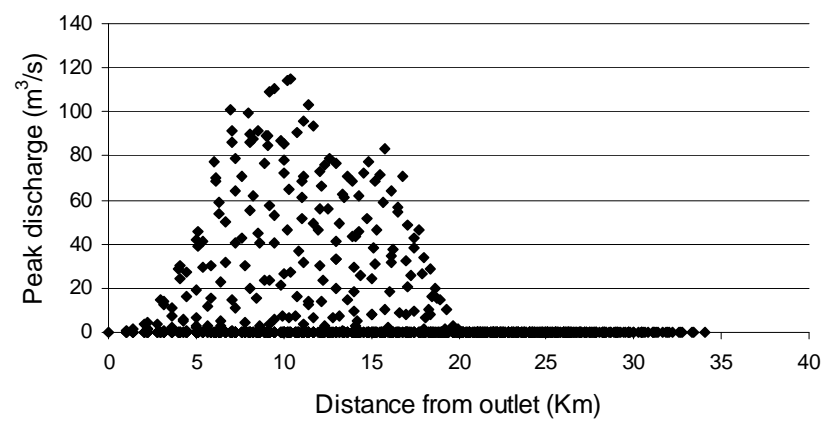

Fig. 10. Peak discharge versus distance from the outlet for each starting location of the flooding cell.

Table 1. Global sensitivity indexes.

\begin{tabular}{lrr}
\hline Factor & Main effect & Total effect \\
\hline Speed & 0.08 & 0.69 \\
Movement direction & 0.01 & 0.31 \\
Starting point & 0.30 & 0.91 \\
\hline
\end{tabular}

1. Using rainfall input into a hydrological model based on rain gauge data neglects the rain spatial structure because the gauges represent sparse point samples. Radar data visually represents the storm spatial structure but, as hydrological model input, there is no explicit representation of this spatial structure. In the current ap- proach, the convective rain cell properties serve as explicit input to the hydrological model and thus their linkage with hydrological response is better determined.

2. Rain data resolution in rainfall-runoff models is very important (Faures et al., 1995; Michaud and Sorooshian, 1994; Andreassian et al., 2001). In research conducted in the Neckar watershed, south-west Germany (Bardossy and Das, 2008), it was found that increasing rain gauge density increases spatial knowledge about the rain and improves the hydrological model results. Another factor is the rain spatial variance. In areas with high rain spatial variance the accuracy of the rain fields is more important (Segond et al., 2007; Yatheendradas et al., 2008). Representing rain fields with modeled rain cells, as done in the current study, provides continuous field presentation using mathematical equations. Hence, it can be modified to fit any required resolution both in time and space.

3. Rainfall data input (based on gauge and radar data) are known to have large uncertainties and their effects on hydrological prediction have been investigated (Faures et al., 1995; Michaud and Sorooshian, 1994; Villarini and Krajewski, 2010). However, the rain uncertainties investigated concern mainly rain magnitudes while uncertainties in rain patterns (e.g., location, direction, rain area) were neglected. The present approach to represent rain storm allows investigating rainfall patterns uncertainties, for example using the GLUE method described 

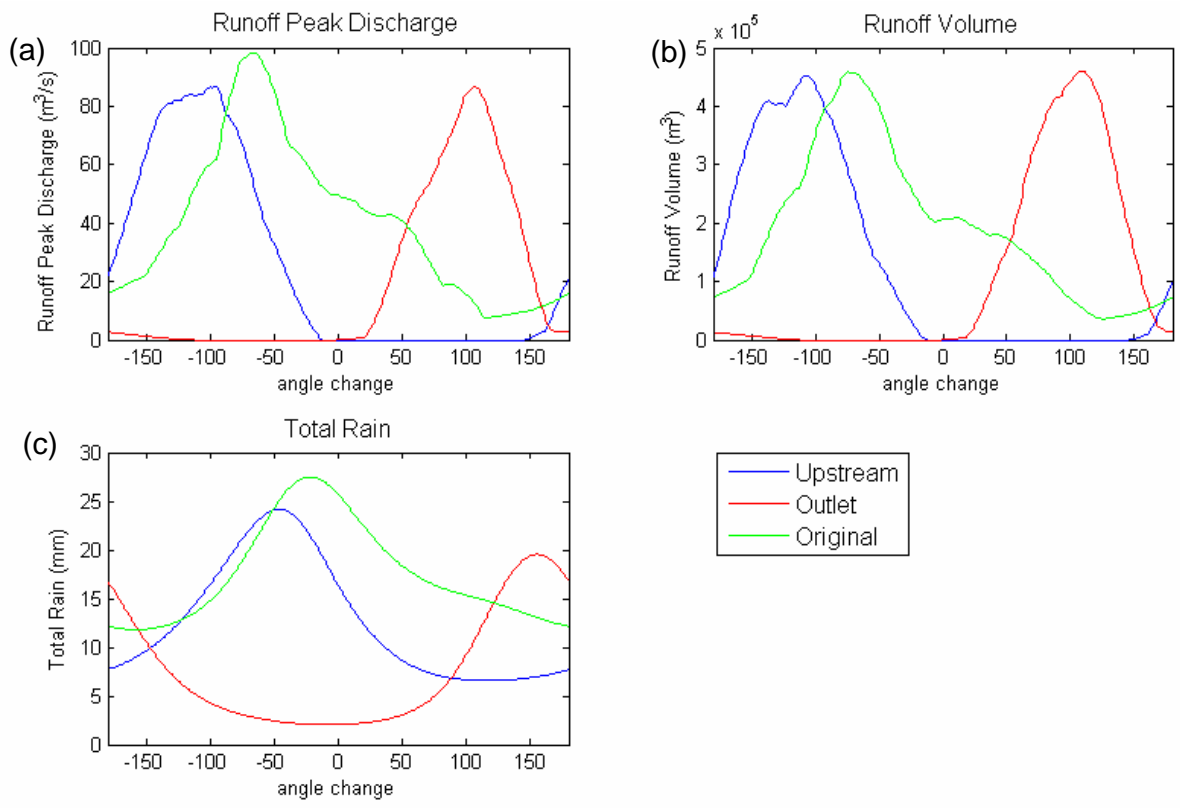

Fig. 11. Changes in (a) outlet runoff peak discharge, (b) runoff volume and (c) total rain as a function of cell direction of movement for three starting locations: original position (green), outlet (red) and upstream (blue). The $\mathrm{x}$ axis is the angle difference relative to the cell's original direction.
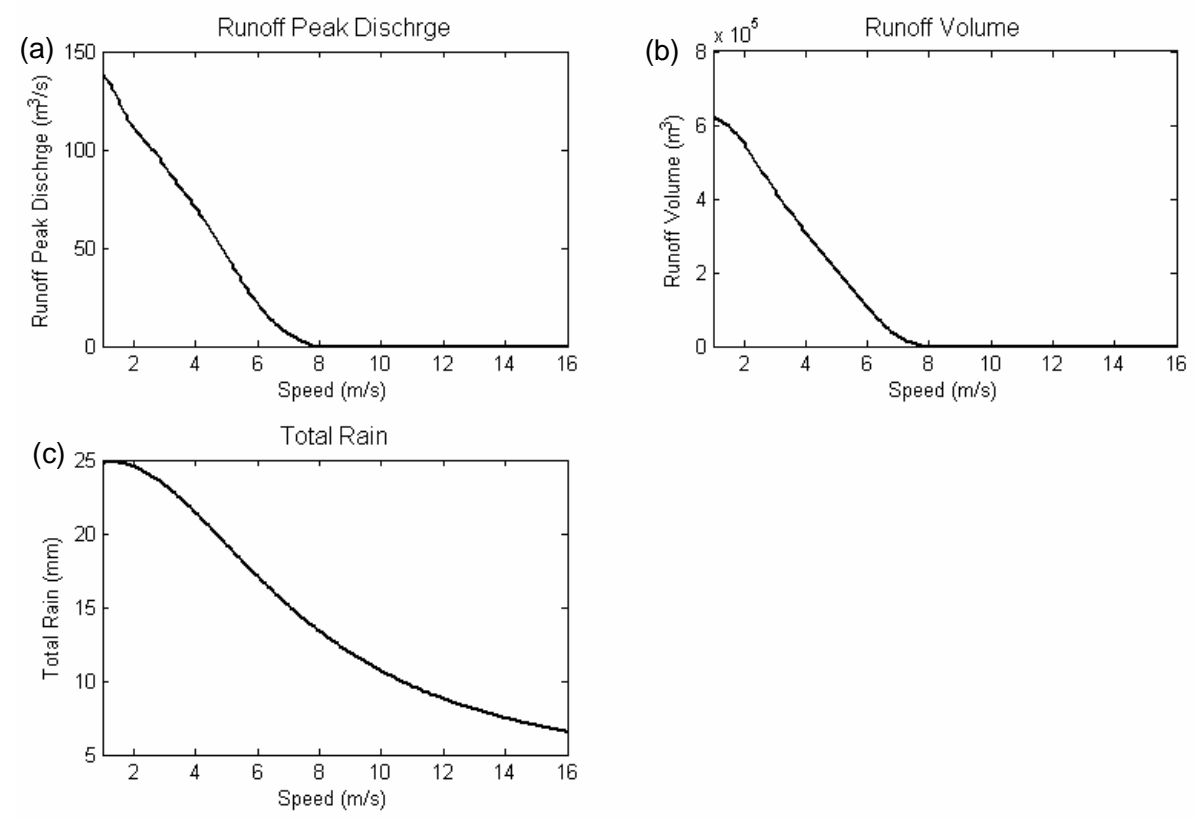

Fig. 12. Changes in: (a) peak discharge, (b) runoff volume and (c) total rain as a function of the flooding cell's speed.

in Beven and Freer (2001), and their hydrological impacts.

4. Design storms are used for planning hydrological systems, usually as an input to a rainfall-runoff model. Rain data are usually represented as local rain at a point or as rain maps for a certain duration and return period
(Chow et al., 1988). Bocchiola et al. (2003) suggested three methods to produce a design storm for hydrological simulations. The first is to use observed rainfall for a long period and, from it to derive the hydrographs using a hydrological model. The second is used when rain observations are not available but the Depth-Duration 
Frequency curves (DDF) of this location are available. For example, Boni et al. (2007) neglected the spatial distribution of the rain, and produced hyetographs for the same rain duration but for different return periods using a known DDF. The third method is based on the Monte-Carlo simulation to generate stochastic rain fields that are fed into the hydrological model to simulate the runoff. All of these methods do not use the actual rain or use it with almost no flexibility. Using the method described in this paper it is possible to create data for a design storm based on real storm data typical of the area. These data can then be very flexible and can be changed easily, by varying the rain rates and also other features such as cell velocity, size, direction and others. In addition, the statistical characteristics of rain cells for a certain area can be computed and thus design storms for different return periods can be estimated.

5. Using the model described here and by altering rain cell characteristics, a maximum runoff peak discharge of about $150 \mathrm{~m}^{3} / \mathrm{s}$ was obtained, which is about threefold the peak discharge obtained from the original rain cell. A similar conclusion was reached by Smith (2000) who demonstrated that peak discharge can be maximized by storm speed and direction. It is interesting to put this enhancement in relation to the envelope curve of the region. It can be shown that the obtained peak discharge falls inside the envelope curves for the Negev area (Meirovich et al., 1998) and that the maximum flood for watersheds of the same area as the Beqa watershed can produce a runoff peak of up to about $700 \mathrm{~m}^{3} / \mathrm{s}$. This implies that the model does not overestimate runoff and, although the highest peak measured in the Beqa watershed was $240 \mathrm{~m}^{3} / \mathrm{s}$ (December, 1951), much higher discharges are possible in this watershed. It is suggested that by using the present approach one can determine the flooding potential of a given storm and how close it can get to the maximal value presented by the envelope curve.

\section{Conclusions}

1. The rain cell model produced rain cells that could adequately simulate the original rain storm.

2. Mathematical representation of rain cells allows one to change their characteristics and to test the watershed sensitivity to these changes.

3. The hydrological response of the Beqa watershed is sensitive mainly to the location of the rain cell. The cell's speed is also important - a cell that dwells longer over the watershed will produce higher flow peak.
4. For the event discussed in this paper, the peak flow may be tripled by relatively small changes in starting location, speed and direction.

Acknowledgements. The research project was funded by the Israel Science Foundation (Grant No. 880/04). Radar data were provided by E. M. S. Mekorot, rain gauge data by the Israel Meteorological Service and runoff flow data by the Israel Hydrological Service. We thank Simon Berkowicz for his help in paper editing. We also thank the journal editor and two anonymous reviewers for their helpful comments.

Edited by: N. Verhoest

\section{References}

Ahrens, D. C.: Meteorology Today-An Introduction to Weather, Climate, and the Environment, 7th ed., Brooks-Cole-Thomson Learning, 2003.

Andreassian, V., Perrin, C., Michel, C., Usart-Sanchez, I., and Lavabre, J.: Impact of imperfect rainfall knowledge on the efficiency and the parameters of watershed models, J. Hydrol., 250, 206-223, 2001.

Arnaud, P., Bouvier, C., Cisneros, L., and Dominguez, R.: Influence of rainfall spatial variability on flood prediction, J. Hydrol., 260, 216-230, 2002.

Bahat, Y., Grodek, T., Lekach, J., and Morin, E.: Rainfall-runoff modeling in a small hyper-arid catchment, J. Hydrol., 373, 204217, 2009.

Bárdossy, A. and Das, T.: Influence of rainfall observation network on model calibration and application, Hydrol. Earth Syst. Sci., 12, 77-89, doi:10.5194/hess-12-77-2008, 2008.

Barnolas, M., Rigo, T., and Llasat, M. C.: Characteristics of 2-D convective structures in Catalonia (NE Spain): an analysis using radar data and GIS, Hydrol. Earth Syst. Sci., 14, 129-139, doi:10.5194/hess-14-129-2010, 2010.

Beven, K. and Freer, J.: Equifinality, data assimilation, and uncertainty estimation in mechanistic modelling of complex environmental systems using the GLUE methodology, J. Hydrol., 249, 11-29, 2001.

Bocchiola, D., De Michele, C., and Rosso, R.: Review of recent advances in index flood estimation, Hydrol. Earth Syst. Sci., 7, 283-296, doi:10.5194/hess-7-283-2003, 2003.

Boni, G., Ferrari, S., L., Glannoni, F., Roth, G., and Rudari, R.: Flood probability analysis for un-gauged watersheds by means of a simple distributed hydrologic model, Adv. Water Resour., 30, 2135-2144, doi:10.1016/j.advwatres.2006.08.009, 2007.

Bonnifait, L., Delrieu, G., Le Lay, M., Boudevillain, B., Masson, A., Belleudy, P., Gaume, E., and Saulnier, G. M.: Distributed hydrologic and hydraulic modelling with radar rainfall input: reconstruction of the 8-9 September 2002 catastrophic flood event in the Gard region, France, Adv. Water Resour., 32, 1077-1089, doi:10.1016/j.advwatres.2009.03.007, 2009.

Capsoni, C., Fedi, F., Magistroni, C., Paraboni, A., and Pawlina, A.: Data and Theory for a New Model of the Horizontal Structure of Rain Cells for Propagation Applications, Radio Sci., 22, 395404, 1987a.

Capsoni, C., Fedi, F., and Paraboni, A.: A Comprehensive Meteorologically Oriented Methodology for the Prediction of Wave- 
Propagation Parameters in Telecommunication Applications Beyond $10 \mathrm{Ghz}$, Radio Sci., 22, 387-393, $1987 \mathrm{~b}$.

Chang, C. L.: Influence of moving rainstorms on watershed responses, Environ. Eng. Sci., 24, 1353-1360, doi:10.1089/ees.2006.0220, 2007.

Chow, V. T., Maidment, D., and Mays, L.: Applied Hydrology, McGraw-Hill Book Company, New York, USA, 1988.

Cowpertwait, P. S. P.: A comparison of three stochastic multisite precipitation occurrence generators, Water Resour. Res., 46, 280-292, doi:10.1029/2010WR009728, 2010.

Cox, D. R. and Isham, V.: A simple spatial-temporal model of rainfall, Proc. R. Soc. London Ser. A-Math. Phys. Eng. Sci., 415, 317-328, 1988.

Dayan, U. and Sharon, D.: Meteorological Parameters for Discriminating between Widespread and Spotty Storms in the Negev, Israel J. Earth Sci., 29, 253-256, 1980.

Dayan, U. and Morin, E.: Flash flood producing rainstorms over the Dead Sea: a review, Special Paper 401: New Frontiers in Dead Sea Paleoenvironmental Research, 401, 53-62, 2006.

Dixon, M. and Wiener, G.: TITAN - Thunderstorm Identification, Tracking, Analysis, and Nowcasting -A radar-based methodology, J. Atmos. Ocean. Tech., 10, 785-797, 1993.

Doswell, C. A., Brooks, H. E., and Maddox, R. A.: Flash flood forecasting: an ingredients-based methodology, Weather Forecast., 11, 560-581, 1996.

Faures, J. M., Goodrich, D. C., Woolhiser, D. A., and Sorooshian, S.: Impact Of Small-Scale Spatial Rainfall Variability On Runoff Modeling, J. Hydrol., 173, 309-326, 1995.

Feral, L., Mesnard, F., Sauvageot, H., Castanet, L., and Lemorton, J.: Rain cells shape and orientation distribution in southwest of France, 1st European Conference on Radar Meterology, Bologna, Italy, 2000, ISI:000089473300051, 1073-1078, 2000.

Feral, L., Sauvageot, H., Castanet, L., and Lemorton, J.: HYCELL - A new hybrid model of the rain horizontal distribution for propagation studies: 1. Modeling of the rain cell, Radio Sci., 38, 1056, doi:10.1029/2002rs002802, 2003.

Gabellani, S., Boni, G., Ferraris, L., von Hardenberg, J., and Provenzale, A.: Propagation of uncertainty from rainfall to runoff: a case study with a stochastic rainfall generator, Adv. Water Resour., 30, 2061-2071, doi:10.1016/j.advwatres.2006.11.015, 2007.

Gupta, V. K. and Waymire, E. C.: A stochastic kinematic study of subsynoptics pace-time rainfall, Water Resour. Res., 15(3), 637644, 1979

Han, L., Fu, S. X., Yang, G., Wang, H. Q., Zheng, Y. G., and Lin, Y. J.: A stochastic method for convective storm identification, tracking and nowcasting, Prog. Natl. Sci., 18, 1557-1563, doi:10.1016/j.pnsc.2008.06.006, 2008.

Johnson, J., MacKeen, P., Witt, A., Mitchell, E., Stumpf, G., Eilts, M., and Thomas, K.: The storm cell identification and tracking algorithm: an enhanced WSR-88D algorithm, Weather Forecast., 13, 263-276, 1998.

Kahana, R., Ziv, B., Enzel, Y., and Dayan, U.: Synoptic climatology of major floods in the Negev Desert, Israel, Int. J. Climatol., 22, 867-882, doi:10.1002/Joc.766, 2002.

Karklinsky, M. and Morin, E.: Spatial characteristics of radar-derived convective rain cells over southern Israel, Meteorologische Zeitschrift, 15, 513-520, doi:10.1127/09412948/2006/0153, 2006.
Leonard, M., Lambert, M. F., Metcalfe, A. V., and Cowpertwait, P. S. P.: A space-time Neyman-Scott rainfall model with defined storm extent, Water Resour. Res., 44, W09402, doi:10.1029/2007WR006110, 2008.

Marco, J. B. and Valdes, J. B.: Partial area coverage distribution for flood frequency analysis in arid regions, Water Resour. Res., 34, 2309-2317, 1998.

Meirovich, L., Ben-Zvi, A., Shentsis, I., and Yanovich, E.: Frequency and magnitude of runoff events in the arid Negev of Israel, J. Hydrol., 207, 204-219, 1998.

Mehrotra, R., Srikanthan, R., and Sharma, A.: Spatial-temporal rainfall modelling for flood risk estimation, Journal of Hydrology, 331, 1-2, 280-292, 2006.

Michaud, J. D. and Sorooshian, S.: Effect Of Rainfall-Sampling Errors On Simulations Of Desert Flash Floods, Water Resour. Res., 30, 2765-2775, 1994.

Morin, E., Goodrich, D. C., Maddox, R. A., Gao, X. G., Gupta, H. V., and Sorooshian, S.: Spatial patterns in thunderstorm rainfall events and their coupling with watershed hydrological response, Adv. Water Res., 29, 843-860, doi:10.1016/j.advwatres.2005.07.014, 2006.

Morin, E. and Gabella, M.: Radar-based quantitative precipitation estimation over Mediterranean and dry climate regimes, J. Geophys. Res.-Atmos., 112, D20108, doi:10.1029/2006JD008206, 2007.

Morin, E., Jacoby, Y., Navon, S., and Bet-Halachmi, E.: Towards flash-flood prediction in the dry Dead Sea region utilizing radar rainfall information, Adv. Water Res., 32, 1066-1076, 2009.

Northrop, P.: A clustered spatial-temporal model of rainfall, Proc. Roy. Soc. a-Math. Phys. Eng. Sci., 454, 1875-1888, 1998.

Rinehart, R. E. and Garvey, E. T.: 3-Dimensional Storm Motion Detection By Conventional Weather Radar, Nature, 273, 287 289, 1978.

Saltelli, A., Ratto, M., Tarantola, S., and Campolongo, F.: Sensitivity analysis practices: strategies for model-based inference, Reliab. Eng. Syst. Safe., 91, 1109-1125, 2006.

Saulnier, G. M. and Le Lay, M.: Sensitivity of flash-flood simulations on the volume, the intensity, and the localization of rainfall in the Cevennes-Vivarais region (France), Water Resour. Res., 45, W10425, doi:10.1029/2008WR006906, 2009.

Segond, M. L., Wheater, H. S., and Onof, C.: The significance of spatial rainfall representation for flood runoff estimation: a numerical evaluation based on the Lee catchment, UK, J. Hydrol., 347, 116-131, doi:10.1016/j.jhydrot.2007.09.040, 2007.

Shah, S. M. S., Oconnell, P. E., and Hosking, J. R. M.: Modelling the effects of spatial variability in rainfall on catchment response. 1. Formulation and calibration of a stochastic rainfall field model, J. Hydrol., 175, 67-88, 1996.

Singh, V. P.: Effect of spatial and temporal variability in rainfall and watershed characteristics on stream flow hydrograph, Hydrol. Proc., 11, 1649-1669, 1997.

Smith, J. A., Baeck, M. L., Morrison, J. E., and Sturdevant-Rees, P.: Catastrophic rainfall and flooding in Texas, J. Hydrometeorol., 1, 5-25, 2000.

Syed, K. H., Goodrich, D. C., Myers, D. E., and Sorooshian, S.: Spatial characteristics of thunderstorm rainfall fields and their relation to runoff, J. Hydrol., 271, 1-21, 2003.

van Werkhoven, K., Wagener, T., Reed, P., and Tang, Y.: Rainfall characteristics define the value of streamflow observations for 
distributed watershed model identification, Geophys. Res. Lett., 35, L11403, doi:10.1029/2008g1034162, 2008.

Villarini, G. and Krajewski, W. F.: Review of the Different Sources of Uncertainty in Single Polarization Radar-Based Estimates of Rainfall, Surv. Geophys., 31, 107-129, doi:10.1007/s10712-0099079-x, 2010.

von Hardenberg, J., Ferraris, L., and Provenzale, A.: The shape of convective rain cells, Geophys. Res.h Lett., 30, 2280, doi:10.1029/2003g1018539, 2003.

Wheater, H. S., Chandler, R. E., Onof, C. J., Isham, V. S., Bellone, E., Yang, C., Lekkas, D., Lourmas, G., and Segond, M. L.: Spatial-temporal rainfall modelling for flood risk estimation, Stoch. Environ. Res. Risk Assess., 19, 403-416, 2005.

Willems, P.: A spatial rainfall generator for small spatial scales, J. Hydrol., 252, 126-144, 2001.

Yatheendradas, S., Wagener, T., Gupta, H., Unkrich, C., Goodrich, D., Schaffner, M., and Stewart, A.: Understanding uncertainty in distributed flash flood forecasting for semiarid regions, Water Resour. Res., 44, W05s19, doi:10.1029/2007wr005940, 2008.
Younger, P. M., Freer, J. E., and Beven, K. J.: Detecting the effects of spatial variability of rainfall on hydrological modelling within an uncertainty analysis framework, Hydrol. Process., 23, 19882003, doi:10.1002/hyp.7341, 2009.

Ziv, B., Dayan, U., and Sharon, D.: A mid-winter, tropical extreme flood-producing storm in southern Israel: Synoptic scale analysis, Meteorol. Atmos. Phys., 88, 53-63, doi:10.1007/s00703003-0054-7, 2005.

Zoccatelli, D., Borga, M., Zanon, F., Antonescu, B., and Stancalie, G.: Which rainfall spatial information for flash flood response modelling? A numerical investigation based on data from the Carpathian range, Romania, J. Hydrol, 394(1-2), 148161. doi:10.1016/j.jhydrol.2010.07.019, 2010. 